\title{
KAJIAN PELAKSANAAN E-TILANG UNTUK ANGKUTAN BARANG
}

\author{
* Fedrickson Haradongan ${ }^{1}$ \\ ${ }^{1}$ Pusat Litbang Jalan dan Perkeretaapian Kemenhub
}

*Email Korespondensi:

arasimanullang@gmail.com

\section{ARTIKEL INFORMASI}

Diterima:

25 Juni 2021

Direvisi:

12 Juli 2021

Dipublikasi:

22 Juli 2021

\begin{abstract}
ABSTRAK
Penerapan E-Tilang bagi angkutan barang telah mulai diberlakukan dari awal maret tahun 2018. Sistem e-tilang di jembatan timbang memungkinkan proses tilang bisa berjalan dengan lebih cepat, sehingga kedua belah belah pihak (petugas dan pelanggar lalu lintas) tidak perlu membuang banyak waktu untuk proses persidangan. Sistem yang menggunakan aplikasi elektronik ini juga akan memudahkan proses kelanjutan dari tilang, sehingga pelanggar lebih mudah dalam menyelesaikan perkara tilang yang sedang dijalaninya. Bukan hanya itu saja, bagi petugas, sistem ini juga akan memungkinkan terjadinya transparansi di dalam proses tilang itu sendiri. E-Tilang tentu akan dapat menekan aksi pungli yang sering terjadi pada sistem tilang manual, di mana kemungkinan kesalahan prosedur dan kelalaian oleh oknum petugas bisa saja terjadi. Sistem E-tilang menggantikan sistem tilang manual yang menggunakan menggunakan blanko/surat tilang, dimana pengendara yang melanggar akan dicatat melalui aplikasi yang dimiliki database UPPKB (Unit Pelaksana Penimbangan Kendaraan Bermotor). Etilang seharusnya memiliki kelebihan pelayanan yang lebih cepat dari pada tilang konvensional. Kelebihannya adalah sistem ini sangat praktis dan cepat. Penerapan sistem tilang elektronik (E-tilang) ini untuk memfasilitasi kecepatan dan kemudahan, keterbukaan pelaksanaan proses tilang atau sebagai pengganti proses tilang di tempat. Penerapan E-tilang angkutan barang sebenarnya sebuah pilihan penindakan yang efektif kepada pelanggaran over dimensi dan over load angkutan barang. Walaupun demikian belum dapat dikatakan bahwa pelaksanaan E-tilang angkutan barang ini efektif karena proses digitalisasi E-tilang angkutan barang di Indonesia masih belum optimal (membutuhkan waktu berhari-hari).
\end{abstract}

Kata Kunci: E-Tilang, Angkutan Barang, Pungutan Liar,UPPKB

\section{PENDAHULUAN}

Tilang elektronik yang biasa disebut E-Tilang ini adalah digitalisasi proses tilang, dengan memanfaatkan teknologi diharapkan seluruh proses tilang akan lebih efisien dan juga efektif juga membantu petugas terkait dalam manajemen administrasi. Penerapan E-Tilang bagi angkutan barang telah mulai diberlakukan dari awal maret tahun 2018. Sistem e-tilang di UPPKB (d/h Jembatan Timbang) memungkinkan proses tilang bisa berjalan dengan lebih cepat, sehingga kedua belah belah pihak (petugas dan pelanggar lalu lintas) tidak perlu membuang banyak waktu untuk proses persidangan. Sistem yang menggunakan aplikasi elektronik ini juga 
akan memudahkan proses kelanjutan dari tilang, sehingga pelanggar lebih mudah dalam menyelesaikan perkara tilang yang sedang dijalaninya. Bukan hanya itu saja, bagi petugas, sistem ini juga akan memungkinkan terjadinya transparansi di dalam proses tilang itu sendiri. E-Tilang tentu akan dapat menekan aksi pungli yang sering terjadi pada sistem tilang manual, di mana kemungkinan kesalahan prosedur dan kelalaian oleh oknum petugas bisa saja terjadi.

Proses E-Tilang untuk angkutan barang memang baru beberapa bulan di launching, namun demikian kita harapkan dapat berjalan optimal. Maka dari itu, dipandang perlu melakukan kegiatan studi bagaimana pelaksanaan E-Tilang untuk angkutan barang, sehingga nantinya segala permasalahan dalam pelaksanaan ETilang saat ini diharapkan dapat dijadikan bahan masukan untuk evaluasi pelaksanaan E-Tilang angkutan barang untuk selanjutnya. Dalam penelian ini, lokasi/unit pelaksana UPPKB yang dipilih adalah UPPKB di wilayah Jawa Barat yaitu UPPKB Balonggandu dan UPPKB Losarang.

\section{KAJIAN PUSTAKA}

Sebagai upaya pengawasan dan pengamanan prasarana dan sarana lalu lintas dan angkutan jalan, digunakan alat penimbangan yang dapat menimbang kendaraan bermotor sehingga dapat diketahui berat kendaraan beserta muatannya (PP Nomor 43 Tahun 1993). Alat penimbangan tersebut berupa jembatan timbang yang keberadaannya merupakan salah satu kebijakan untuk melindungi kerusakan jalan akibat muatan lebih serta untuk keselamatan lalu lintas. Alat penimbangan yang dipasang secara tetap tersebut dilengkapi dengan fasilitas penunjang dan dioperasikan oleh pelaksana penimbangan. Fasilitas penunjang yang dimaksud antara lain :

1. Gedung operasional;

2. Lapangan parkir kendaraan;

3. Fasilitas jalan keluar masuk kendaraan;

4. Gudang penyimpanan barang;

5. Lapangan penumpukan barang;

6. Bangunan gedung untuk generator set;

7. Pagar;

8. Perambuan untuk maksud pengoperasian.

Penyelenggaraan penimbangan terhadap alat berat kendaraan beserta muatannya (PP No. 43 Tahun 1993) meliputi :

1. Penentuan lokasi;

2. Pengadaan, pemasangan, dan atau penimbangan;

3. Pengoperasian;

4. Pemeliharaan.

Penentuan lokasi jembatan timbang umumnya berada pada jalan nasional sebagai prasarana pergerakan kendaraan angkutan barang dengan beban muatan yang relatif besar. Berdasarkan Keputusan Menteri Perhubungan Nomor 5 Tahun 1995, penentuan lokasi alat penimbangan yang dipasang secara tetap harus memperhatikan:

1. Rencana umum tata ruang;

2. Jaringan transportasi jalan;

3. Volume lalu lintas harian rata-rata untuk angkutan barang (>150 kend/hr);

4. Kelancaran arus lalu lintas;

5. Kelas jalan;

6. Kondisi topografi lokasi;

7. Tersedia lahan sekurang-kurangnya $4000 \mathrm{~m} 2$;

8. Efektivitas pengawasan berat kendaraaan beserta muatannya.

Sedangkan kegiatan yang dilakukan di jembatang timbang meliputi :

1. Penimbangan kendaraan berat beserta muatannya;

2. Pemeriksaan dimensi kendaraan;

3. Pemeriksaan surat uji kendaraan; 
4. Pemeriksaan muatan, di mana yang muatan meliputi :

a. Barang umum : sayuran, ikan kering, dll.

b. Barang strategis : baja, semen, dll.

c. Sembako : beras, gula, dll.

\section{Fungsi dan Kewenangan Jembatan Timbang (UPPKB)}

Berdasarkan PP Nomor 25 Tahun 2000 tentang Program Pembangunan Nasional, segala ketentuan mengenai jembatan timbang yang meliputi penetapan lokasi dan pengelolaan jembatan timbang serta penetapan standar batas maksimum muatan dan berat kendaraan pengangkutan barang merupakan kewenangan propinsi sebagai daerah otonom. Penyelenggaraan penimbangan pada jembatan timbang menjadi tanggung jawab Dinas Lalu Lintas dan Angkutan Jalan yang pengoperasiaannya dilaksanakan oleh Unit Pelaksana Teknis Dinas, (Perda Jateng Nomor 4 Tahun 2001) tentang Tarif Ijin Dispensasi Kelebihan Muatan. Sedangkan fungsi dan misi jembatan timbang meliputi :

1. Menjaga jalan dari kerusakan akibat beban muatan;

2. Memantau kendaraan angkutan barang dan penempatan muatan;

3. Sebagai sarana pengumpulan data lalu lintas untuk proses perencanaan dan pengendalian transportasi.

\section{Evaluasi, Monitoring dan Kinerja Jembatan Timbang (UPPKB)}

Sebagai suatu proses, manajemen jembatan timbang mengenal suatu urutan pelaksanaan yang logis yang menggambarkan bahwa ada tindakan - tindakan manajemen untuk mencapai sasaran-sasaran yang telah ditetapkan. Secara umum proses tersebut meliputi:

\section{Planning}

Merupakan pemikiran atau gagasan awal tentang suatu rencana sebelum kegiatan dilaksanakan. Manfaat dari fungsi perencanaan di atas adalah sebagai alat pengawasan maupun pengendalian kegiatan atau pedoman pelaksanaan kegiatan, serta sarana untuk memilih dan menetapkan kegiatan yang diperlukan.

\section{Organizing}

Berupa tindakan-tindakan guna mempersatukan kumpulan kegiatan manusia yang mempunyai pekerjaan masing-masing sehingga berhubungan satu sama lain dengan tata cara tertentu dan berinteraksi dengan lingkungannya dalam rangka mendukung tercapainya tujuan / sasaran secara efisien. Manfaat dari fungsi organisasi adalah merupakan pedoman pelaksanaan fungsi dimana pembagian tugas serta hubungan tanggung jawab dan kewenangan terlihat jelas.

\section{Actuating}

Berupa tindakan untuk menyelaraskan seluruh anggota organisasi dalam kegiatan pelaksanaan, serta agar seluruh anggota organisasi dapat bekerjasama dalam pencapaian tujuan bersama.

Manfaat dari fungsi pelaksanaan ini adalah terciptanya keseimbangan tugas, hak dan kewajiban masing-masing bagian dalam organisasi.

4. Controlling

Dalam arti menuntun atau memantau, mengkaji dan bila perlu mengadakan koreksi agar hasil kegiatan sesuai dengan yang telah ditentukan. Jadi dalam fungsi ini, hasil-hasil pelaksanaan kegiatan selalu diukur dan dibandingkan dengan rencana. Fungsi dari pengawasan tersebut meliputi :

a) Penetapan standar pelaksanaan;

b) Penentuan ukuran-ukuran pelaksanaan;

c) Pengukuran pelaksanaan nyata dan membandingkan dengan standar yang telah ditetapkan;

d) Evaluasi penyimpangan yang terjadi;

Pengambilan tindakan koreksi yang diperkirakan bila pelaksanaan menyimpang dari standar.

\section{METODE}

Studi mengenai pelaksanaan E-Tilang untuk angkutan barang di Jembatan Timbang/UPPKB ini dilakukan dalam beberapa tahapan. Dimulai dari pekerjaan persiapan, mengidentifikasi kebutuhan data, mengidentifikasi masalah, menyiapkan studi pustaka yang akan dipakai, melakukan analisa dan pembahasan sehingga diperoleh hasil dan kesimpulan. 
Metode yang digunakan dalam penelitian ini adalah observasi lapangan. Obyek penelitiannya adalah Jembatan Timbang/UPPKB yang berada dalam wilayah Jawa Barat (dalam hal ini UPPKB Balonggandu dan UPPKB Losarang). UPPKB Balonggandu dan UPPKB Losarang berada di jalan nasional (jalur pantura) yang merupakan jalur strategis di Pulau Jawa. Jalur ini merupakan salah satu tempat bongkar-muat barang yang berasal dari atau akan dikirim dari Pulau Jawa. Banyak truk dengan plat nomor luar kota dan juga luar Jawa yang melintas pada jalur ini. Sedangkan data yang diperlukan dalam penelitian ini adalah data primer dan data sekunder. Data primer diperoleh dengan metode wawancara kepada narasumber (petugas) dan informan (pengemudi truk) serta metode observasi. Wawancara dilakukan terhadap sepuluh sopir dan beberapa petugas dilapangan. Observasi yang dilakukan di UPPKB Balonggandu dan UPPKB Losarang guna mengetahui secara langsung proses yang berlangsung di lapangan. Data sekunder diperoleh dari telaah dokumen dan referensi yang terkait dengan penelitian ini. Proses analisis data dimulai dari pengumpulan data, pengolahan data, hasil, kesimpulan dan rekomendasi.

\section{HASIL DAN PEMBAHASAN}

\section{UPPKB Wilayah Jawa Barat}

Jembatan Timbang atau UPPKB (Unit Pelaksana Penimbangan Kendaraan Bermotor) adalah unit di bawah Kementerian Perhubungan Republik Indonesia yang bertugas melakukan pengawasan, pencatatan dan penindakan bagi angkutan barang yang beroperasi di ruas jalan sebagai upaya untuk menjaga kondisi prasarana jalan raya dan keselamatan lalu lintas di jalan raya (Peraturan Menteri Perhubungan RI no. 134 Tahun 2015). Dan merupakan salah satu kebijakan pemerintah untuk melakukan perlindungan bagi jalan terhadap kerusakan akibat muatan berlebih dan keselamatan lalu lintas. Fungsi tersebut meliputi tata cara pemuatan,jenis yang diangkut, tujuan, berat barang, jenis, dimensi dan tipe kendaraan serta kelaikan kendaraan.

Jenis kendaraan yang dilakukan penimbangan adalah semua angkutan barang kecuali angkutan kontainer, tangki BBM dan BBG, angkutan barang berbahaya dan angkutan alat berat. Pemasangan jembatan timbang atau UPPKB dilakukan di ruas jalan nasional dan ruas jalan strategis nasional seperti kawasan industri, sentra produksi, pelabuhan, jalan tol dan kawasan strategis lainnya.

Sesuai Undang Undang Nomor 22 Tahun 2009 tentang Lalu Lintas dan Angkutan jalan, pasal 169, ayat (1) : Pengemudi dan/atau Perusahaan Angkutan Umum barang wajib mematuhi ketentuan mengenai tata cara pemuatan, daya angkut, dimensi Kendaraan, dan kelas jalan. Ayat (2) : Untuk mengawasi pemenuhan terhadap ketentuan sebagaimana dimaksud pada ayat (1) dilakukan pengawasan muatan angkutan barang. Ayat (3) : Pengawasan muatan angkutan barang dilakukan dengan menggunakan alat penimbangan. Ayat (4): Alat penimbangan sebagaimana dimaksud pada ayat (3) terdiri atas: alat penimbangan yang dipasang secara tetap; atau alat penimbangan yang dapat dipindahkan. Berdasarkan Pasal 169 tersebut, jenis-jenis pelanggaran angkutan barang yang dikenakan sangsi E-Tilang Ditjen Perhubungan Darat meliputi:

a. Pelanggaran Dokumen Kendaraan dan ketidaksesuaian dokumen perjalanan/surat muatan dengan jenis barang yang diangkut (masa berlaku Buku Uji, keabsahan dan keaslian dari Bukti Lulus Uji);

b. Pelanggaran kelebihan daya angkut mobil barang atau berat muatan melebihi 5\% (Overload) dari daya angkut kendaraan yang ditetapkan dalam bukti lulus uji;

c. Pelanggaran tata cara pemuatan barang;

d. Pelanggaran dimensi kendaraan;

e. Pelanggaran MST terhadap kelas jalan; dan

f. Pelanggaran persyaratan teknis dan laik jalan.

Sanksi bagi pelanggaran angkutan barang di jalan sebagaimana Pasal 307 jo Pasal 169, Undang-undang Nomor 22 Tahun 2009 tentang lalu Lintas dan Angkutan Jalan, sebagai berikut :

Pasal 307 : Setiap orang yang mengemudikan Kendaraan Bermotor Angkutan Umum Barang yang tidak mematuhi ketentuan mengenai tata cara pemuatan, daya angkut, dimensi kendaraan sebagaimana dimaksud dalam Pasal 169 ayat (1) dipidana dengan pidana kurungan paling lama 2 (dua) bulan atau denda paling banyak Rp500.000,00 (lima ratus ribu rupiah). Pasal 169 :

a. Pengemudi dan/atau Perusahaan Angkutan Umum barang wajib mematuhi ketentuan mengenai tata cara pemuatan, daya angkut, dimensi Kendaraan, dan kelas jalan (ayat 1) 
b. Untuk mengawasi pemenuhan terhadap ketentuan sebagaimana dimaksud pada ayat dilakukan pengawasan muatan angkutan barang (ayat 2)

c. Pengawasan muatan angkutan barang dilakukan dengan menggunakan alat penimbangan (ayat 3).

d. Alat penimbangan terdiri atas: alat penimbangan yang dipasang secara tetap; atau alat penimbangan yang dapat dipindahkan (ayat 4).

Agar pekerjaan berjalan sesuai dengan visi, misi, aturan dan program kerja maka dibutuhkan pengontrolan. bentuk supervisi, pengawasan, inspeksi dan audit, sehingga sejak dini dapat diketahui penyimpangan-penyimpangan yang terjadi.

Berdasarkan Undang Undang Nomor 22 Tahun 2009 pasal 169, ayat (1) semua kendaraan angkutan barang, (kecuali angkutan peti kemas, mobil tangki bahan bakar minyak/dan atau bahan bakar gas dan alat berat, sesuai Peraturan Dirjen Perhubungan Darat Nomor SK.736/AJ.108/DRJD/2017), wajib melakukan penimbangan di UPPKB.

Sesuai ketentuan yang ada, pelaksanaan e-tilang di UPPKB dilakukan non stop 24 jam. Implementasii etilang diharapkan selain meminimalkan interaksi antar-pelanggar dan petugas di lapangan juga mempercepat waktu proses dari proses awal penilangan sampai putusan dendan dan pengambilan barang bukti yang menunjukkan selesainya proses e-tilang. Dan kelebihan muatan harus diturunkan.

\section{Evaluasi Penimbangan Angkutan Barang}

Sebagaimana telah diuraikan bahwa semua kendaraan angkutan barang wajib melakukan penimbangan. Dari penimbangan ini akan dapat diketahui mana yang melanggar mana yang tidak. Kendaraan angkutan barang yang melanggar, khususnya kelebihan muatan akan dilakukan penilangan. Proses penilangan ini memerlulan waktu beberapa menit, sementara areal UPPKB/tempat parkir bagi kendaraan yang ditilang/mengurus proses tilang kurang memadai. Hal ini berakibat lama waktu kendaraan keluar UPPKB yang tidak sebanding dengan kenadaraan masuk UPPKB berakibat antrian antrian panjang di ruas jalan menjelang masuk UPPKB. Ini sangat yang mengganggu arus lalu lintas di ruas jalan ini yang dpat berpotensi timbulnya kecelakaan. Dalam kondisi demikian Proses penimbangan kendaraan/proses e-tilang tidak dapat diterapkan bagi seluruh kendaraan yang melanggar karena pekasnanaannya tidak dapat dilaksanakan non stop 24 jam. Kelebihan muatan saat ini belum dapat diturunkan karena beberapa kendala antara lain keterbatasan alat timbang dan SDM.

Saran :

Diupayakan durasi proses penimbangan sampai dengan eitilang dipercepat dengan memperluas areal parkir dan alat timbang dan penambahan SDM yang kompeten

\section{Evaluasi Durasi Waktu Proses E-Tilang}

Meskipun Pelanggar yang telah membayar denda maksinal tidak perlu hadir dalam persidangan, namun denda nominal/denda riil yang diputuskan oleh Kejaksaan prosesnya memerlukan waktu 4 (empat) hari.

Sisa denda (selisih antara denda maksimal dengan denda nominal hasil amar putusan kejaksaan yang dapat diambil di Bank BRI ini dengan menunjukkan Surat Keterangan dari Kejaksaan wilayah tempat Pelanggara melakukan pelanggaran. Tanpa bukti surat keterangan dari Kejaksaan ini sisa denda tidak dapat diambil.

Apabila Pelanggar berdomisili jauh dari daerah lokasi Kejaksaan tempat yang bersangkutan melakukan pelanggaran, untuk mendapatkan surat keterangan Kejaksaan sebagai bukti pengambilan sisa denda akan menyulitkan atau menjadi kendala bagi si Pelanggar.

Saran :

Terus berdiskusi dengan pihak Kejaksaan agar amar putusan dapat diproses lebih cepat dan Surat keterangan bukti pengambilan sisa denda tidak harus diambil di Kejaksaan TKP, selain itu perbanyak bank yang dapat digunakan untuk melakukan pembayaran denda maupun pengambilan sisa denda tilang.

\section{Evaluasi Pelanggar Yang Membayar dan Tidak Membayar Denda}

Sebagai barang bukti pelanggaran, Buku KIR/Buku Uji kendaraan angkutan milik Pengemudi yang melanggar akan disita. Buku KIR/Buku Uji ini akan dikembalikan setelah Pelanggar membayar denda maksimal Rp.500.000,- Berdasarkan informasi yang diperoleh saat melakukan survei di UPPKB Balonggandu dan Losarang, hanya 10\% pelanggar yang membayar denda maksimal dan mengambil Buku KIR/Buku Uji 
yang disita, sementara $90 \%$ pengemudi yang melanggar tidak membayar denda dan tidak mengambil Buku KIR/Buku Uji. Besarnya persentase Pelanggar yang tidak membayar denga dan tidak mengambil Buku KIR/Buku Uji yang disita ini menurut informasi Pelanggar dapat menerbitkan Buku KIR/Buku Uji yang baru hanya dengan membayar Rp 75.000.

Saran :

Sebaiknya penerbitan Buku KIR/Buku Uji melalui verifikasi yang cermat dan diajukan dengan data dudung, dan bukti pelanggaran e-tilang, bila perlu dengan biaya yang besar sehingga tidak disalahgunakan untuk lolos dari denda pelanggaran e-tilang angkutan barang.

\section{KESIMPLAN DAN SARAN}

\section{Kesimpulan}

1. Sistem E-tilang menggantikan sistem tilang manual yang menggunakan menggunakan blanko/surat tilang, dimana pengendara yang melanggar akan dicatat melalui aplikasi yang dimiliki database UPPKB. E-tilang seharusnya memiliki kelebihan pelayanan yang lebih cepat dari pada tilang konvensional. Kelebihannya adalah sistem ini sangat praktis dan cepat. Penerapan sistem tilang elektronik (E-tilang) itu untuk memfasilitasi kecepatan dan kemudahan, keterbukaan pelaksanaan proses tilang atau sebagai pengganti proses tilang di tempat. Khususnya di UPPKB yang merupakan salah satu program Menteri Perhubungan sebagai salah satu upaya pemberantasan pungli. Program aplikasi E-tilang angkutan barang saat ini dianggap belum maksimal dari sisi waktu pelayanan.

2. Penerapan E-tilang merupakan sebuah pilihan yang efektif yang mencapai sasaran dalam pelaksanaan tilang kepada pelanggaran over dimensi dan over load angkutan barang walaupun belum dapat dikatakan bahwa pelaksanaan E-tilang angkutan barang ini efektif, karena penerapan E-tilang angkutan barang di Indonesia masih dalam tahap uji coba dan dari uji coba tersebut akan diadakan evaluasi untuk perbaikan pelayanan Etilang selanjutnya. Namun, belum semua pengemudi angkutan barang di Indonesia melek teknologi. Masih banyak dari mereka yang belum tahu mengenai adanya E-tilang sehingga perlunya sosialisasi yang lebih gencar dan merata kepada pengemudi tersebut. Beberapa manfaat bagi pelanggar lalu lintas dengan adanya system E-Tilang adalah :

a. Transparansi. Adanya mekanisme pelaporan maupun penyebaran informasi penyimpangan tindakan aparat publik di dalam kegiatan penyelenggaraan pemerintahan.

b. Pemberdayaan. Melalui E-Tilang ini masyarakat akan mengetahui segala informasi mengenai tindakan yang dapat dikategorikan pelanggaran lalu lintas serta hukuman akibat tindakan tersebut. Sehingga diharapkan masyarakat dapat menularkan sikap tertib lalu lintas setelah mengetahui peraturan yang ada kepada orang di sekelilingnya agar tidak melanggar peraturan yang ada.

c. Responsif. Responsivitas pihak berwenang akan lebih tinggi dan semakin cepat tanggap dan lebih responsive terhadap aduan masyarakat dalam hal lalu lintas.

d. Keadilan. Dalam layanan E-Tilang setiap pelangar yang melakukan perbuatan pelanggaran yang sama akan mendapatkan denda atau hukuman yang sama tanpa pandang bulu.

\section{Saran}

Dibalik kelebihannya, terdapat beberapa kelemahan pelaksanaan E-Tilang sehingga perlu dipikirkan beberapa solusi untuk memperbaiki dan meminimalisir kekurangan sistem E-Tilang tersebut, diantaranya adalah :

1) Aksesibilitas jaringan aplikasi. Sistem aplikasi menggunakan jaringan dualband 3G/4G dimana jika ketersediaan sinyal sedang buruk akibat cuaca maka layanan pun akan terganggu. Sehingga petugas tetap harus menyediakan layanan tambahan (wifi) untuk mengantisipasi system error.

2) Pelanggaran seharusnya terintegerasi dengan data Buku KIR, sehingga dapat dipantau status pelanggaran angkutan barang saat membuat/memperpanjang Buku KIR.

\section{Ucapan Terima Kasih}

Penulis menyampaikan ucapan terima kasih yang sebesar-besarnya kepada: 
1) Bapak Kepala Pusat Penelitian dan Pengembangan Transportasi Jalan dan Perkeretaapian selaku Pengarah Utama.

2) UPPKB Balonggandu dan UPPKB Losarang.

3) Rekan rekan peneliti di Badan Litbang yang telah memberikan masukan dan saran untuk penelitian ini.

\section{DAFTAR PUSTAKA}

Undang Nomor 22 Tahun 2009 tentang Lalu Lintas dan Angkutan jalan, pasal 169

Peraturan Menteri Perhubungan RI no. 134 Tahun 2015

Peraturan Dirjen Perhubungan Darat Nomor SK.736/AJ.108/DRJD/2017

PP Nomor 43 Tahun 1993

Keputusan Menteri Perhubungan Nomor 5 Tahun 1995

Direktorat Jenderal Bina Marga. 1997. Manual Kapasitas Jalan Indonesia. Jakarta.

Nazir, M. 2005. Metodologi Penelitian. Bogor. Ghalia Indonesia.

Gay, L. R., \& Diehl, P. L. 1992. Research Methods for Business and Management. New York: MacMillan

Publishing Company.

Sugiyono. 2010. Metode Penelitian Pendidikan. Bandung: Alfabeta. 